\title{
Eunicidae (Annelida: Polychaeta) associated with Phragmathopoma caudata Morch, 1863 and some coral reefs from Veracruz, Gulf of Mexico
}

\author{
JESÚS ANGEL DE LEÓN-GONZÁLEZ ${ }^{1}$ and VICTORIA DÍAZ CASTAÑEDA ${ }^{2}$ \\ ${ }^{1}$ Laboratorio de Biosistemática, Facultad de Ciencias Biológicas, Universidad Autónoma de Nuevo León, Ap. Postal 5, \\ Suc. "F", San Nicolás de los Garza, N.L.66451, México. E-mail: jdeleon@fcb.uanl.mx \\ ${ }^{2}$ CICESE, Km 107, Highway Tijuana-Ensenada, Apdo. Postal 2732, Ensenada, B.C., México.
}

\begin{abstract}
SUMMARY: This study analyses species in the family Eunicidae obtained in the intertidal zones of Veracruz, Mexico. The specimens collected were associated with a sabellariid Phragmatopoma caudata Morch, 1863, and collected directly by scuba diving from some coral reefs in Veracruz. Twelve species were found, six of whish are reported for the first time in the area: Eunice mutilata Webster, 1884, Eunice panamena (Chamberlin, 1919), Eunice pellucida Kinberg, 1865, Eunice unifrons (Verrill, 1900), Marphysa aransensis Treadwell, 1939 and Nematonereis unicornis (Grube, 1840). Furthermore, the descriptions of two new species of the genera Eunice and Marphysa are included.

Keywords: Polychaeta, Eunicidae, Veracruz, Golfo de México.

RESUMEN: Eunícidos (AnNelida: Polychaeta) asociados con Phragmathopoma CAUDATA Morch, 1863 y algunos ARRECIFES CORALINOS DE VERACRUZ, GOLFO DE MÉXICO. - Este estudio analiza las especies de la familia Eunicidae obtenidos de la zona de entremareas de Veracruz, México. Los especimenes fueron recolectados asociadas con formaciones arenosas del sabelárido Phragmatopoma caudata Morch, 1863, y directamente por medio de buceo autónomo en algunos arrecifes coralinos en Veracruz. Doce especies fueron encontradas, seis de las cuales se citan por primera vez para el área: Eunice mutilata Webster, 1884, Eunice panamena (Chamberlin, 1919), Eunice pellucida Kinberg, 1865, Eunice unifrons (Verrill, 1900), Marphysa aransensis Treadwell, 1939 y Nematonereis unicornis (Grube, 1840). Además, se incluye la descripción de dos nuevas especies de los géneros Eunice y Marphysa.
\end{abstract}

Palabras clave: Polychaeta, Eunicidae, Veracruz, Golfo de México.

\section{INTRODUCTION}

The state of Veracruz, located on the eastern coast of Mexico (Gulf of Mexico), possesses a great variety of coastal environments, from sandy beaches, rocky shores, coralline reefs and islands. Although this ecosystem supports a high diversity of habitats, knowledge of the family Eunicidae in these zones is brief. Previously 12 eunicid species were recorded for this area, 7 of these were reported by Rioja (1946, 1958 and 1960): Eunice anten- nata, Eunice aphroditois, Eunice cariboea, Eunice rubra, Lysidice ninetta, Marphysa minima and Palola siciliensis. Later, other researchers extended the list of known eunicid species including: SalazarVallejo (1981) reported E. cariboea, Eunice norvegica and Paramarphysa longula; Horta-Puga (1982) mentioned E. cariboea and Nematonereis hebes; de León-González (1985) reported L. ninetta and P. longula; Reyes-Barragán and Salazar-Vallejo (1991) reported Marphysa amadae and Marphysa sanguinea for La Mancha lagoon and Sanchez-Wall 
(1992) mentioned Eunice filamentosa. The main objective of this study was to increase the knowledge of the polychaete fauna of Veracruz

\section{MATERIAL AND METHODS}

Specimens were obtained from a range of investigations carried out along the coast of Veracruz during 1992-2003, and were collected in intertidal sand formations of the polychaete sabellariid Phragmatopoma caudata, in Punta Morro, Boquilla de Oro, Villa Rica, rocks of Veracruz Harbour and Villa del Mar Beach. In all localities an area of approximately $25 \mathrm{~cm}^{2}$ of sabellariid tubes was sampled, extending to the rock beneath. In the laboratory, the sabellariid tubes were broken apart to extract the associated fauna. Other specimens were collected from dead coral in coralline environments at Sacrificios Island, Santiaguillo Island and La Gallega; and terracotta plates (Pl-1, 2, 3) from Blanca, Hornos and Pajaros Reefs. Furthermore, some specimens were collected from the structure that collects water in the Aquarium of Veracruz. The type and non-type materials were deposited in the Polychaete collection of the Universidad Autonoma de Nuevo Leon (UANL). Table 1 shows a list of sampling stations and locations.

\section{RESULTS}

\section{Eunice antennata (Lamarck, 1818)}

Eunice antennata Hartman, 1944: 115, Figs. 154-156; Day, 1967 384, Fig. 17.2 k-q; Imajima, 1967: 433, Fig. 10 a-m; Miura, 1977a: 7, Fig. 3 a-1 (in part); 1986: 290, Fig. 17; Fauchald, 1970: 20; Fig. 1 a-c; 1992:57, Fig. 11 a-e; Gardiner, 1976: 181, Fig. 22 c-j; Dueñas, 1981: 93; Ibarzabal, 1989: 7, Fig. 3 a-h; Carrera-Parra \& Salazar-Vallejo, 1998a: 1500, Fig. 1 a -e.

Material examined. 53 specimens. Punta Morro, Stn. PM-01 (2), July 2000; Boquilla de Oro, Stn. BO-01 (12), July 2000; Stn. BO02 (1), July 2000; Stn. BO-04 (12), July 2000; Villa Rica, Stn. VR01 (3), 10 August 1999; Stn. VR-03 (1), 10 August 1999; Villa del Mar Beach, Stn. V-04 (1), 11 August 1999; Aquarium of Veracruz, Stn. AV-01 (3), July 2000; Pajaros Reef, Stn. Pl -1 (1), 14 April 2002; Hornos Reef, Stn. Pl -1 (1), 16 January 2001; Stn. Pl -1 (1), 14 April 2001; Pl -1 (1), 11 December 2001; Stn. Pl -1 (5), 14 December 2001; Stn. Pl -1 (1), 16 January 2002; Stn. Pl -2 (2), 16 January 2002; Stn. Pl -1 (1), 15 March 2002; Stn. Pl -3 (2), 15 March 2002; Stn. Pl -2 (1), 24 June 2002; Stn. Pl -1 (1), 14 April 2002; Stn. Pl -1 (1), 14 July 2002.

Distribution. This species was originally described from the Gulf of Suez. It is known from tropical and subtropical waters around the world. In
TABLE 1. - Location and position of sampling stations.

\begin{tabular}{|c|c|c|c|}
\hline Station & Latitude (N) & Longitude (W) & Depth (m) \\
\hline \multicolumn{4}{|l|}{ Punta Morro } \\
\hline PM-01 & $19^{\circ} 51^{\prime} 36.7^{\prime \prime}$ & $96^{\circ} 27^{\prime} 44.4^{\prime \prime}$ & 0.0 \\
\hline PM-03 & $19^{\circ} 51^{\prime} 37.8^{\prime \prime}$ & $96^{\circ} 27^{\prime} 37.6^{\prime \prime}$ & 0.0 \\
\hline PM-04 & $19^{\circ} 51^{\prime} 36.9^{\prime \prime}$ & $96^{\circ} 27^{\prime} 34.4^{\prime \prime}$ & 0.0 \\
\hline \multicolumn{4}{|l|}{ Boquilla de Oro } \\
\hline BO-01 & $19^{\circ} 50^{\prime} 40.0^{\prime \prime}$ & $96^{\circ} 26^{\prime} 46.8^{\prime \prime}$ & 0.0 \\
\hline BO-02 & $19^{\circ} 49^{\prime} 59.1^{\prime \prime}$ & $96^{\circ} 26^{\prime} 46.1^{\prime \prime}$ & 0.0 \\
\hline BO-03 & $19^{\circ} 49^{\prime} 58.3^{\prime \prime}$ & $96^{\circ} 26^{\prime} 47.6^{\prime \prime}$ & 0.0 \\
\hline BO-04 & $19^{\circ} 49^{\prime} 46.2^{\prime \prime}$ & $96^{\circ} 26^{\prime} 47.9^{\prime \prime}$ & 0.0 \\
\hline \multicolumn{4}{|l|}{ Villa Rica } \\
\hline VR-01 & $19^{\circ} 40^{\prime} 30.7^{\prime \prime}$ & $96^{\circ} 23^{\prime} 33.3^{\prime \prime}$ & 0.0 \\
\hline VR-02 & $19^{\circ} 40^{\prime} 31.8^{\prime \prime}$ & $96^{\circ} 23^{\prime} 34.8^{\prime \prime}$ & 0.0 \\
\hline VR-03 & $19^{\circ} 40^{\prime} 32.0^{\prime \prime}$ & $96^{\circ} 23^{\prime} 36.6^{\prime \prime}$ & 0.0 \\
\hline \multicolumn{4}{|c|}{ Rocks of Veracruz Harbour } \\
\hline VES-02 & $19^{\circ} 12^{\prime} 00.8^{\prime \prime}$ & $96^{\circ} 07^{\prime} 17.0^{\prime \prime}$ & 0.0 \\
\hline VES-05 & $19^{\circ} 11^{\prime} 43.0^{\prime \prime}$ & $96^{\circ} 07^{\prime} 21.7^{\prime \prime}$ & 0.0 \\
\hline \multicolumn{4}{|c|}{ Villa del Mar Beach } \\
\hline $\mathrm{V}-03$ & $19^{\circ} 10^{\prime} 53.3^{\prime \prime}$ & $96^{\circ} 07^{\prime} 22.0^{\prime \prime}$ & 0.0 \\
\hline $\mathrm{V}-04$ & $19^{\circ} 10^{\prime} 53.9^{\prime \prime}$ & $96^{\circ} 07^{\prime} 21.4^{\prime \prime}$ & 0.0 \\
\hline $\mathrm{V}-05$ & $19^{\circ} 10^{\prime} 53.4^{\prime \prime}$ & $96^{\circ} 07^{\prime} 21.9^{\prime \prime}$ & 0.0 \\
\hline V-06 & $19^{\circ} 10^{\prime} 53.9^{\prime \prime}$ & $96^{\circ} 07^{\prime} 22.2^{\prime \prime}$ & 0.0 \\
\hline \multicolumn{4}{|c|}{ Aquarium of Veracruz } \\
\hline AV-01 & $19^{\circ} 11^{\prime} 12.3^{\prime \prime}$ & $96^{\circ} 07^{\prime} 09.4^{\prime \prime}$ & 5.0 \\
\hline \multicolumn{4}{|l|}{ La Gallega Reef } \\
\hline $\begin{array}{l}\text { V-01 } \\
\text { Paiaros Reef }\end{array}$ & $19^{\circ} 12^{\prime} 48.0^{\prime \prime}$ & $96^{\circ} 07^{\prime} 25.0^{\prime \prime}$ & 1.5 \\
\hline $\begin{array}{c}\text { Pajaros Reef } \\
\text { Pl }-1, \mathrm{Pl}-2\end{array}$ & $19^{\circ} 11^{\prime} 38.0^{\prime \prime}$ & $96^{\circ} 05^{\prime} 48.0^{\prime \prime}$ & 3.0 \\
\hline \multicolumn{4}{|l|}{ Blanca Reef } \\
\hline Pl-1, Pl-2, Pl-3 & $19^{\circ} 08^{\prime} 45.0^{\prime \prime}$ & $96^{\circ} 00^{\prime} 54.0^{\prime \prime}$ & 3.0 \\
\hline \multicolumn{4}{|l|}{ Hornos Reef } \\
\hline \multirow{2}{*}{\multicolumn{2}{|c|}{ Sacrificios Island }} & $91^{\circ} 11^{\prime} 00.0^{\prime \prime}$ & 3.0 \\
\hline & $19^{\circ} 10^{\prime} 30.2^{\prime \prime}$ & $96^{\circ} 05^{\prime} 38.4^{\prime \prime}$ & 2.0 \\
\hline \multicolumn{4}{|c|}{ Santiaguillo Island } \\
\hline lis & $19^{\circ} 082$ & 954830.7 & 1.5 \\
\hline
\end{tabular}

Mexico, records of this species are from the peninsula of Baja California, Baja California Sur, Sonora, Nayarit, Guerrero, Oaxaca and the Revillagigedo Islands in the Pacific Ocean, and Veracruz and Quintana Roo in the Atlantic Ocean.

\section{Eunice cariboea Grube, 1856}

Eunice (Nicidion) cariboea Hartman, 1944: 123, Pl. 7, Figs. 157163; Miura, 1977b: 67, Fig. 3 a-n; 1986: 290, Fig. 17; Ibarzabal, 1989: 13: 7 a-f.

Eunice cariboea Fauchald, 1992:98, fig. 29 g-q; Carrera-Parra \& Salazar-Vallejo, 1998a: 1501, Fig. 2 f-j; Zanol, et al., 2000: 449.

Material examined. 83 specimens. Villa Rica, Stn. VR-01 (1), July 2000; Aquarium of Veracruz, Stn. AV-01 (1), July 2000; La Gallega Reef, Stn. V-01A (2), 14 November 1992; Stn. V-01A (32), July 2000; Stn. V-01B (46), July 2000; Pajaros Reef, Stn. Pl -1 (1), 16 January 2002.

Distribution. Originally described from Christiansted St. Croix, Virgin Islands. Widely distributed in tropical and subtropical coasts, and in the Western Atlantic it is known from Bermuda to Brazil. In Mexico this species is known from Baja California Sur, Sonora, Sinaloa and Guerrero in the Pacific, and from Veracruz in the Atlantic. 
Eunice filamentosa Grube, 1856

Eunice filamentosa Hartman, 1944: 107, pl. 6, Figs. 123; Day, 1967: 392, Fig. 17.5 f -h; Fauchald, 1970: 31, pl. 3, Figs. c -g; 1992:138, Fig. 45 g -q; Gardiner, 1976: 182, Fig. 22 o -t; Dueñas, 1981: 94; Ibarzabal, 1989: 9, Fig. 4 a -h; Carrera-Parra and SalazarVallejo, 1998a: 1502, Fig. 4 g-1; Zanol, et al., 2000: 453.

Material examined. 3 specimens. La Gallega Reef, Stn. V-01A (1), 14 November 1992; Stn. V-01B (2), July 2000.

Distribution. Amphiamerican in tropical and subtropical waters, known also from South Africa. In Mexico this species is known from the peninsula of Baja California, Sonora, Sinaloa and Oaxaca in the Pacific, and from Veracruz and Quintana Roo in the Atlantic.

\section{Eunice mutilata Webster, 1884}

Eunice mutilata Webster, 1884: 315, Fig. 36 a-d; Hartman, 1944 113, pl. 6, Figs. 140-141; Ebbs, 1966: 534, Fig. 10 a-j; Fauchald, 1992: 232, Fig. 77 f -n; Zanol, et al., 2000: 455.

Material examined. 1 specimen. La Gallega Reef, Stn. V-01A (1), July 2000.

Distribution. Amphiamerican in tropical waters. In Mexico this species is known from the Revillagigedo Islands, Jalisco and Nayarit in the Pacific, and in the Atlantic it had been recorded previously only from Quintana Roo. This is the first record in Veracruz.

\section{Eunice panamena (Chamberlin, 1919)}

Leodice panamena Chamberlin, 1919: 256, pl. 59, Figs. 4-8, pl. 60 , figs. 1-5.

Eunice panamena Fauchald, 1992: 249, Fig. 82 f -1.

Material examined. 8 specimens. Hornos Reef., Stn. Pl -1 (2), 16 June 2002; Stn. Pl -2 (4), 30 May 2003; Stn. Pl -3 (2), 30 May 2003.

Remarks. The specimens reported here have branchiae present from chaetiger 5, palps and antennae with numerous moniliform articulations, dorsal cirri with 3-4 cylindrical articulations, and hammerheaded aciculae. They vary slightly from the original description in the following features: observed specimens have 12 branchial filaments and subacicular hooks starting on chaetiger 24, whereas the holotype (see Fauchald, 1992) has up to 8 branchial filaments and subacicular hooks starting on chaetiger 27 .

Distribution. Amphiamerican in tropical waters, and known from the eastern Pacific near Panama. This is the first record from the Atlantic.

\section{Eunice pellucida Kinberg, 1865}

Eunice pellucida Fauchald, 1992: 261, Fig. 87 a-f; Carrera-Parra and Salazar-Vallejo, 1998a: 1507.

Material examined. 1 specimen. Hornos Reef, Stn. Pl -1 (1), 14 July 2002

Remarks. This specimen resembles those described by Fauchald (1992) in the following characters: first 4 ventral cirri thick, tapering, basally inflated from chaetiger 5; branchiae starting on chaetiger 5 , pectinate, with up to 8 filaments; subacicular hooks yellowish, tridentate, starting on chaetigers 21-23, 1 per parapodium; dorsal cirri without articulations. The specimen differs slightly in the following characters: median antenna reaching chaetiger 11 in syntypes, and reaching chaetiger 3 in the present one; eyes absent in syntypes and present in our specimen; maxilla II with 7 teeth in syntype while this specimen has 5 on the left side and 6 on the right side.

Distribution. Caribbean, from St. Thomas Island. This is the first record from Mexican littoral regions.

\section{Eunice romanvivesi n. $\mathrm{sp}$.}

(Fig. 1)

Material examined. 4 specimens. Pajaros Reef, Stn. Pl -1 (1), 30 May 2003; Holotype (UANL 6327) Hornos Reef, Stn. Pl -2, 14 July 2002; Paratypes (UANL 6328) Hornos Reef, Stn. Pl -1 (2), 30 May 2003 .

Description. Holotype complete, with 70 chaetigers, $15 \mathrm{~mm}$ long, $1 \mathrm{~mm}$ wide including parapodia, and yellowish in colour. Prostomium rounded anteriorly, longer than wide. Median sulcus not seen. One pair of rounded black eyes posterior to palps and lateral to the bases of lateral antennae. Ceratophores ring-shaped in all antenniform structures. Palps and antennae with cylindrical articulations basally, becoming drop-shaped distally. Middle antenna longer, reaching chaetiger 5, with 7 articulations; right lateral antenna with 5 articulations, left one with 4; palps with 2 and one, respectively. First ring of peristomium two thirds of total peristomial length. One pair of short and smooth peristomial cirri, reaching middle part of first persistomial ring (Fig. 1A).

First parapodium smaller than others. Dorsal cirri digitiform not articulated, longer than ventral cirri in all chaetigers. Ventral cirri conical on anterior parapodia (Fig. 1B), and digitiform in the middle and 


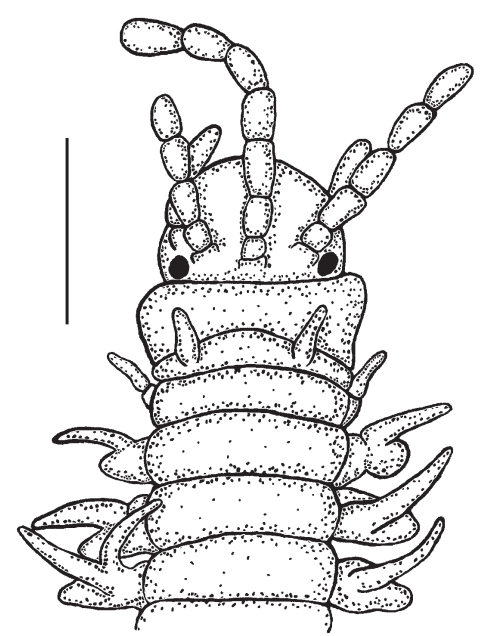

A

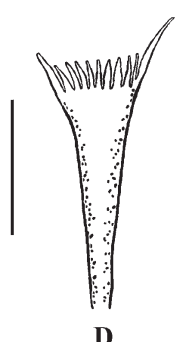

西
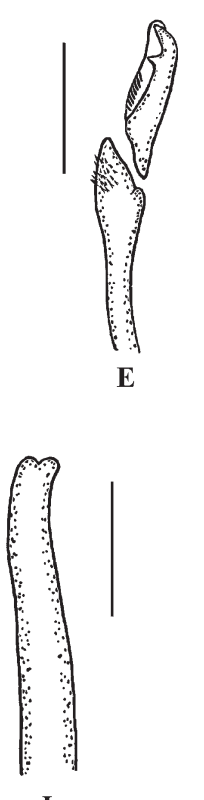

I
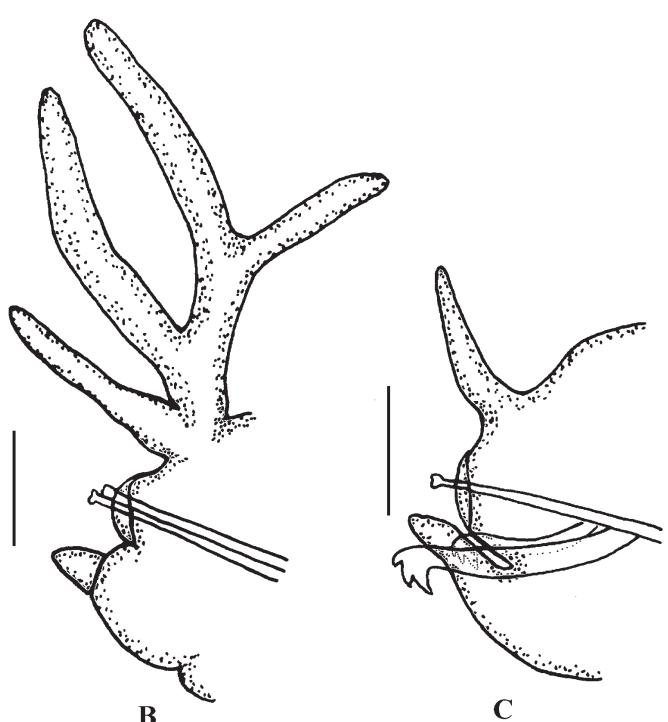

C
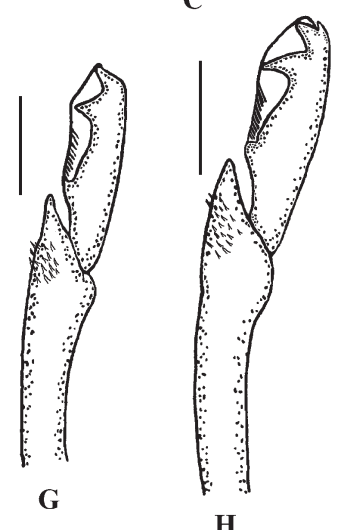

$\mathbf{F}$

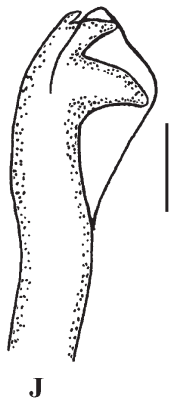

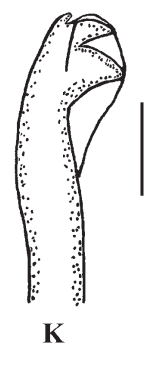

Fig. 1. - Eunice romanvivesi n. sp.: A, anterior end, dorsal view; B, chaetiger 10, in anterior view; C, chaetiger 25, in anterior view; D, pectinate chaeta; E, compound falciger from chaetiger $1 ; \mathrm{F}$, compound falciger from chaetiger $10 ; \mathrm{G}$, compound falciger from chaetiger $25 ; \mathrm{H}$, compound falciger from chaetiger 25; I, acicula from chaetiger 10; J, subacicular hook from chaetiger 25; K, subacicular hook from same chaetiger. Scale bars: A $=0.5 \mathrm{~mm}$; B-C $=150 \mu \mathrm{m}$.

posterior ones (Fig. 1C). Branchiae from chaetiger 4 on left side and from chaetiger 5 on right side, to chaetiger 14 . Up to 4 branchial filaments until chaetiger 7 .

Limbate chaetae marginally serrated. Pectinate chaetae with $9-10$ heterodont teeth present from anterior parapodia, (Fig. 1D). Anterior parapodia with bidentate falcigers, those of first chaetiger smaller (Fig. 1E, F); posterior falcigers bidentate (Fig. 1G), and tridentate, the last one with the pri- mary fang longer, triangular, directed slightly down; secondary fang triangular, directed obliquely distally; tertiary fang small, triangular (Fig. 1H). All shafts slightly wide distally, marginally spinulate. First chaetiger with 3 yellowish aciculae, distally blunt; from chaetiger 2 , with aciculae bifid distally (Fig. 1I), some inferior aciculae tapering distally. Subacicular hooks present from chaetiger 11, 2 per chaetiger, one long and one short, tridentate, yellowish, and hooded (Fig. 1J, K). 
Pygidium with terminal anus and 4 anal cirri, dorsal ones larger.

Maxillae not seen on holotype. The paratype (UANL 6328) has the following arrangement: MxI= $1+1 ; \mathrm{MxII}=5+5 ; \mathrm{MxIII}=7+0 ; \mathrm{MxIV}=8+10$; and $\mathrm{MxV}=1-1$. Maxillae III like an arch, not covered by Maxillae II. Maxillae are yellow and soft.

Etymology. The species name is to recognize the valuable support of Miguel Angel Roman-Vives (Aquarium of Veracruz) for the facilities provided during the collection activities in the Marine Park Sistema Arrecifal Veracruzano, Veracruz-Anton Lizardo.

Remarks. One of the main diagnostic characters of Eunice romanvivesi $\mathrm{n}$. sp. is the presence of tridentate falcigers. Others species with this kind of chaetae are Eunice aequalis (Grube, 1878) from Australia, Eunice aucklandica Avernicev (1974) from the Antarctic Ocean, Eunice elseyi (Baird, 1869) from Australia, Eunice havaica (Kinberg, 1865) from Hawaii, Eunice martensi (Grube, 1878) from the Philippines and Eunice miurai CarreraParra \& Salazar-Vallejo (1998b) from the Mexican Caribbean. Only E. aucklandica, E. havaica and E. miurai have both bi- and tridentate falcigers along the body like E. romanvivesi. Eunice aucklandica and $E$. havaica differ from $E$. romanvivesi mainly in the shape of the acicula and the beginning of subacicular hooks; E. aucklandica and E. havaica have straight aciculae, tapering and blunt, and subacicular hooks appearing from chaetiger 18 and 19-23 respectively, while $E$. romanvivesi has hammerheaded aciculae, and subacicular hooks from chaetiger 11. Eunice miurai differs mainly from $E$. romanvivesi in having articulated peristomial and dorsal cirri, while these characters are smooth in the new species.

Distribution. Eunice romanvivesi is only known from the Hornos and Pajaros Reefs in front of Veracruz Harbour.

\section{Eunice unifrons (Verrill, 1900)}

Leodice unifrons Treadwell, 1921: 17, Figs. 21-30, pl. 1, Figs. 5-9. Eunice unifrons Fauchald, 1992: 330-332, Fig. 113 a-j; CarreraParra \& Salazar-Vallejo, 1998a: 1506, Fig. 10 g-j.

Material examined. 11 specimens. Blanca Reef, Stn. Pl -1 (1), 16 April 2002; Stn. Pl -3 (3), 21 May 2002; Stn. Pl -1 (2), 21 July 2002; Stn. Pl -2 (1), 21 July 2002.
Remarks. Specimens reported here differ slightly from type species redescribed by Fauchald (1992) in having a middle antenna with 10 articulations, reaching chaetiger 7 , a lateral antennae with 7 articulations, reaching chaetiger 4 , and palps with 3 to 4 articulations, reaching chaetiger 1; subacicular hooks from chaetiger 22 to 28 ; and maxillary formula: $\mathrm{MxI}=1+1, \mathrm{MxII}=7+10, \mathrm{MxIII}=8+0, \mathrm{MxIV}=$ $7+10, \mathrm{MxV}=1+1$. In comparison, Fauchald (1992) described the middle and lateral antennae as having 4 articulations, and both reaching to chaetiger 2; subacicular hooks from chaetiger 25 (26-31 in other specimens); and maxillary formula: $\mathrm{MxI}=1+1$, $\mathrm{MxII}=8+8, \mathrm{MxIII}=5+0, \mathrm{MxIV}=8+10, \mathrm{MxV}=1+1$.

Distribution. Caribbean Sea and Bermuda. In Mexico this species is known from Quintana Roo. This is the first record from Veracruz.

Lysidice ninetta Audouin and Milne Edwards, 1833

Lysidice ninetta Fauvel, 1923: 411, Fig. 162 a-g; Hartman, 1944: 125; Day, 1967: 403, Fig. 17.8 g -i; Gardiner, 1976: 174, Fig. 21 a -d; Gathof, 1984: 40.6, Fig. 40-3 a-i; George \& Hartmann-Schröder, 1985: 106, Fig. 30 a -d; Ibarzabal, 1989: 15, Fig. 8 a-g; Nuñez et al., 1998: 69, Fig. 14 A-G; Salazar-Vallejo \& Carrera-Parra, 1998: 1483, Fig. $1 \mathrm{f}$-h.

Material examined. 53 specimens. Punta Morro, Stn. PM-03 (4), 10 August 1999; Stn. PM-04 (1), July 2000; Boquilla de Oro, Stn. BO01 (1), 10 August 1999; Stn. BO-01 (6), July 2000; Stn. BO-04 (2), July 2000; Rocks of Veracruz Harbour, Stn. VES-05 (2), July 2000; Villa del Mar beach, Stn. V-04 (4), 11 August 1999; Stn. V-05 (2), July 2000; Stn. V-06 (6), July 2000; Aquarium of Veracruz, Stn. AV-01 (2), July 2000; Pajaros Reef, Stn. Pl -2 (2), 30 May 2003; Hornos Reef, Stn. Pl -1 (2), 14 April 2002; Stn. Pl -1 (6), 30 May 2003; Stn. Pl -2 (1), 30 May 2003; Sacrificios Island, Stn. IS-03 (10), July 2000; Santiaguillo Island, Stn. ISA-02 (2), July 2000.

Distribution. In tropical, subtropical and warm temperate waters, the Red Sea, Mediterranean Sea, and the Indian, Atlantic and Pacific Oceans. In Mexico this species is known from Baja California Sur, Revillagigedo Islands, Nayarit and Guerrero in the Pacific, and from Veracruz, Campeche and Quintana Roo in the Atlantic.

\section{Marphysa aransensis Treadwell, 1939}

Marphysa aransensis Treadwell, 1939: 5, Figs. 16-17; Hartman, 1956: 285; Salazar-Vallejo et al., 1987: 33; Salazar-Vallejo and Carrera-Parra, 1998: 1485, Fig. 3 a-e.

Material examined. 3 specimens. Punta Morro, Stn. PM-01 (1), 10 August 1999; La Gallega Reef, Stn. V-01 (2), 14 November 1992.

Distribution. This species was originally described from Port Aransas, Texas. In Mexico this 


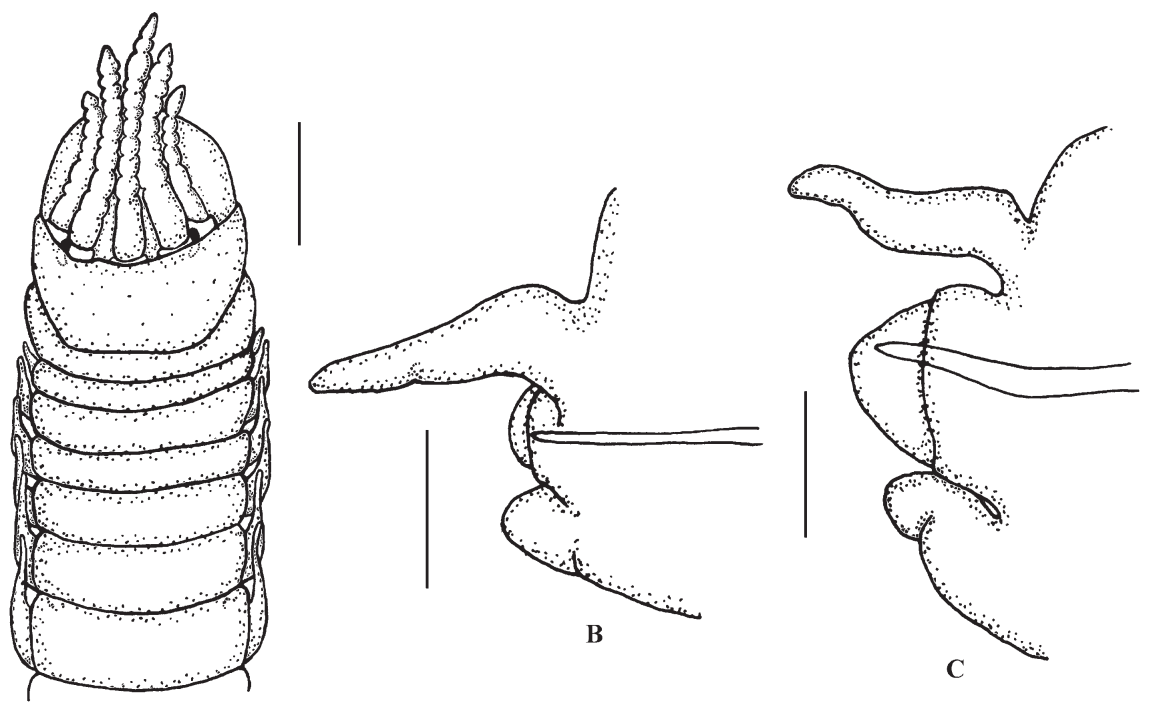

A
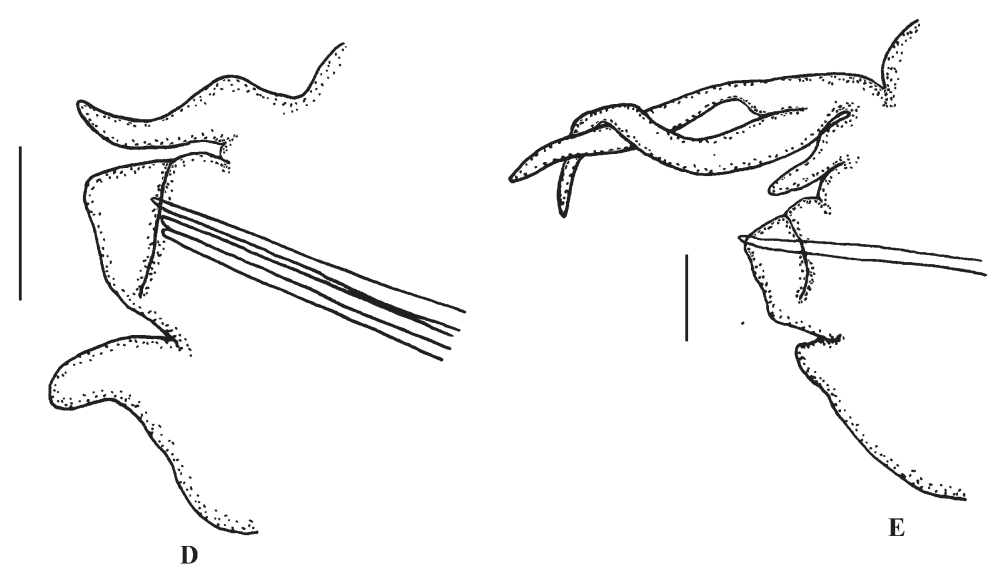

E

Fig. 2. - Marphysa veracruzensis n. sp.: A, anterior end, dorsal view; B, first chaetiger, anterior view; C, chaetiger 10, anterior view; D, chaetiger 20, anterior view; E, chaetiger 50, anterior view; Scale bars: A $=1 \mathrm{~mm}$; B-E $=150 \mu \mathrm{m}$.

species is known from Tamaulipas and Quintana Roo. This is the first record from Veracruz.

Marphysa longula (Ehlers, 1887)

Paramarphysa longula Ehlers, 1887: 99, Pl. 29, Figs. 3-12; Rioja, 1960: 302; Nuñez et al., 1998: 66, Fig. 13 a-h.

Marphysa longula Salazar-Vallejo and Carrera-Parra, 1998: 1489, Fig. $5 \mathrm{f}-\mathrm{j}$.

Material examined. 12 specimens. Punta Morro, Stn. PM-03 (5), 10 August 1999; Rocks of Veracruz Harbour, Stn. VES-02 (2), July 2000; Villa del Mar Beach, Stn. V-03 (1), 09 August 1999; La Gallega Reef, Stn. V-01A (2), 14 November 1992; Hornos Reef, Stn. Pl -1 (1), 30 May 2003; Stn. Pl -2 (1), 30 May 2003.

Distribution. Amphiatlantic. Known from the Canary Islands, Cape Verde Islands, Senegal, Gulf of Guinea, Cuba, Bermuda and Florida. In Mexico this species is known from Veracruz, Yucatan and Quintana Roo in the Atlantic.

\section{Marphysa veracruzensis $\mathrm{n}$. sp.}

(Figs. 2, 3)

Material examined. 28 specimens. Boquilla de Oro, Stn. BO-03 (1), 10 August 1999; Villa Rica, Stn. VR-02 (1), 10 August 1999; Stn. VR-03 (1), 10 August 1999; Stn. BO-01 (5), July 2000; Stn. BO04 (5), July 2000; Villa del Mar beach, Stn. V-03 (1), 11 August 1999; Stn. V-04, Holotype (UANL 6329) and 7 Paratypes (UANL 6330), 9 August 1999; Stn. V-05 (2), 12 July 2000; Stn. V -06 (1), 12 July 2000; Aquarium of Veracruz, Stn. AV-01 (1); 11 July 2000; Sacrificios Island, Stn. IS-03 (2), 13 July 2000.

Description. Holotype complete, with 239 chaetigers, $63 \mathrm{~mm}$ long, $1.3 \mathrm{~mm}$ wide excluding parapodia, and yellowish iridescent color. Prostomium longer than wide, with a pair of subtriangular superior lips, and median sulcus. Ceratophores ring-shaped in all antenniform structures. Palps and antennae slightly wrinkled. Middle antenna reaches chaetiger 4 , lateral antennae reach chaetiger 3 , short palps reach chaetiger 1 . One pair of black reniform eyes between 
lateral antennae and palps. First ring of peristomium about two thirds of total peristomial length (Fig. 2A). No peristomial cirri.

First parapodia smaller than the others (Fig. 2B). Dorsal cirri smooth, always longer than ventral cirri. Postchaetal lobe rounded on first chaetigers (Figs. 2B-C), anterior-middle lobes becomes almost triangular (Figs. 2D-E), posterior lobes not observed (Figs. 3A-B). Ventral cirri absent on posterior parapodia. Pectinate branchiae, with up to 3 filaments, from chaetiger 33 to chaetiger 185, more developed from chaetiger 100 .

Limbate chaetae marginally serrated. Pectinate chaetae present from middle parapodia, with 17-18 teeth, heterodont (Fig. 3C); posterior ones isodont with 14 teeth (Fig. 3D). Anterior parapodia with bidentate falcigers of 3 sizes: a longer one, with the lateral tooth shorter than the distal tooth (Fig. 3E); the middle and small sizes with a lateral and distal tooth triangular, subequal (Figs. 3F-G); all blades with slightly serrated hood. Falcigers on middle and posterior parapodia have only those with a small blade. Shaft slightly wide distally, marginally spinulate. One acicula per parapodium on anterior chaetigers, transitioning to 3 thin aciculae around chaetiger 20. The middle to posterior chaetigers with one acicula per parapodium, blunt-headed, honey-coloured, and darker toward posterior end (Fig. 3H). Subacicular hooks yellowish and bidentate, with hood, present from parapodia 29, and always single. Distal tooth shorter than lateral tooth (Fig. 3I).
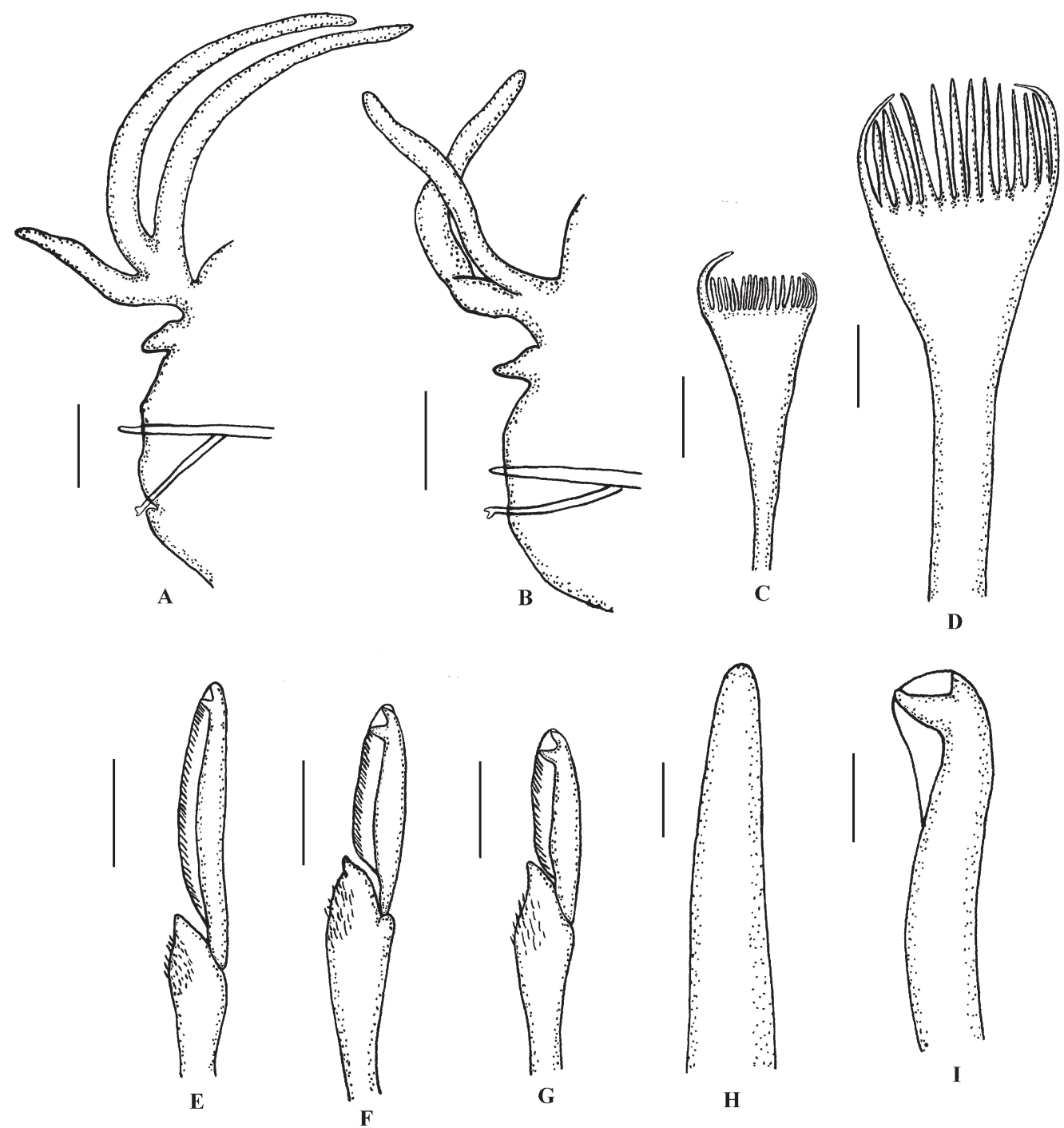

FIG. 3. - Marphysa veracruzensis n. sp.: A. chaetiger 100, in anterior view; B, chaetiger 160, anterior view; C, pectinate chaetae from middle parapodium; D, pectinate chaeta from posterior parapodium; E, F, G, compound falciger from chaetiger 10 ; $\mathrm{H}$, acicula from chaetiger 50 ; I, subacicular hook from chaetiger 160. Scale bars: A-B $=150 \mu \mathrm{m} ; \mathrm{C}-\mathrm{I}=15 \mu \mathrm{m}$. 
Two pairs of anal cirri present; dorsal pair as long as last four chaetigers, ventral pair only an eigth of the length of the dorsal pair.

Maxillae decalcified, yellow with black margin, maxillary formula: $\mathrm{MxI}=1+1, \mathrm{MxII}=3+3$, MxIII= $6+0, \mathrm{MxIV}=6+7, \mathrm{MxV}=1+1$.

Etymology. The species name is taken from Veracruz, the state from which the type locality is described.

Remarks. The specimens of Marphysa veracruzensis vary in some characters: branchiae beginning on chaetiger 17 to 39 , maximal number of branchial filaments 2-3, and subacicular hooks starting on chaetiger 24 to 34 . All specimens have maxillary decalcified apparatus, with the same formula as the holotype. Only 4 specimens with differences on maxillae II (4+4), and another one with differences on maxillae IV $(5+8)$ were seen. The differences between the beginning of the branchiae and subacicular hooks could be due to differences in the size of the specimens.

Marphysa veracruzensis belongs to a group of species with few branchial filaments and compound chaetae consisting of only bidentate falcigers. The most closely related species are Marphysa escobarae Salazar-Vallejo and Carrera-Parra (1998b), Marphysa posterobranchiata Day (1962) and Marphysa regalis Verrill (1900). Marphysa escobarae and $M$. regalis have unidentate subacicular hooks from chaetiger 17 and 21 , respectively. Marphysa posterobranchiata, like M. veracruzensis has bidentate subacicular hooks present. Both species differ mainly in the start position of the branchiae, the maximum number of branchial filaments, the maxillary formula and the type of pectinate chaetae. Marphysa posterobranchiata has branchiae present from chaetiger 84 in a short length of the body, with only one branchial filament; Maxillae II= 5+5, Maxillae IV= 5+10; with only isodont pectinate chaetae. M. veracruzensis, on the otherhand, has branchiae beginning from chaetiger 33 in the holotype, but varying in other specimens between chaetigers 17-39; Maxillae $\mathrm{II}=3+3$, Maxillae IV $=6+7$, and pectinate chaetae of two types, heterodont anteriorly and isodont posteriorly.

Distribution. Villa del Mar Beach, Boquilla de Oro, Villa Rica, and Sacrificios Island, and Veracruz, Mexico.
Nematonereis unicornis Schmarda, 1861

Nematonereis unicornis Fauvel, 1923: 412, Fig. 162 h-h; 1953: 249, Fig. 124 h-n; Day, 1967: 403, Fig. 17.8 j-n; Westheide, 1977: 22, Fig. 8 A-G; Miura, 1979: 40, Fig. 6 a-g; George \& HartmannSchröder, 1985: 114, Fig. 34 a-d; Salazar-Vallejo, 1985: 187; Ibarzabal, 1989: 16, Fig. 9 a-h; Nuñez et al., 1998: 71, Fig. 15 a-e; Salazar-Vallejo \& Carrera-Parra, 1998: 1494, Fig. 8 f-j.

Material examined. 65 specimens. Punta Morro, Stn- PM-01 (1), July 2000; Boquilla de Oro, Stn. BO-03 (1), 10 August 1999; Villa Rica, Stn. VR-03 (1), 10 August 1999; Villa del Mar beach, Stn. V05 (8), July 2000; Stn. V-06 (11), July 2000; La Gallega Reef, Stn. V-01A (1), 14 November 1992; V-01A (14), July 2000; Stn. V-01B (16), July 2000; Pajaros Reef, Stn. Pl -1 (1), 11 December 2001; Stn. Pl -2 (1), 16 June 2002; Stn. Pl -2 (1), 14 July 2002; Stn. Pl -2 (3), 30 May 2003; Blanca Reef, Stn. Pl -2 (1), 24 February 2002; Stn. Pl -1 (1), 24 February 2002; Hornos Reef, Stn. Pl -1 (1), 11 December 2001; Stn. Pl -3 (1), 15 March 2002; Stn. Pl -1 (1), 14 April 2002; Stn. Pl -1 (1), 30 May 2003.

Distribution. In tropical and temperate waters. In Mexico this species is known from the peninsula of Baja California and Sonora in the Pacific, and Quintana Roo in the Atlantic, This is its first record from Veracruz.

Palola siciliensis (Grube, 1840)

Eunice siciliensis Ehlers, 1868: 353, Pl. 16, Figs. 1-7; Fauvel, 1923: 405, Fig. 159 e-m.

Eunice (Palola) siciliensis Day, 1967: 382, Fig. 17.2 a-f.

Palola siciliensis Rioja, 1946: 194; Hartman, 1944: 131; Gardiner, 1976: 178; Ibarzabal, 1989: 16, Fig. 10 a-f; Salazar-Vallejo \& Carrera-Parra, 1998: 1494, Fig. 8 k-n.

Material examined. 79 specimens. Punta Morro, Stn. PM-04 (9), 10 August 1999; Stn. PM-03 (20), July 2000; Boquilla de Oro, Stn. BO-01 (12), 10 August 1999; Stn. BO-01 (4), July 2000; Villa Rica, Stn. VR-01 (1), July 2000; Villa del Mar Beach, Stn. V -06 (7), July 2000; La Gallega Reef, Stn. V-01A (7), July 2000; Santiaguillo Island, Stn. ISA-02 (19), July 2000.

Distribution. In tropical waters around the world. In Mexico this species is known from Baja California Sur, Sonora, Nayarit and Oaxaca in the Pacific, and Veracruz and Quintana Roo in the Atlantic.

\section{ACKNOWLEDGMENTS}

The authors are grateful to the Comision Nacional para el Conocimiento y Uso de la Biodiversidad (CONABIO), projects $\mathrm{S} 035$ and AA001, for financial support for this work. We thank the personnel of the Aquarium of Veracruz for the facilities provided during the collection visits in the Parque Arrecifal Veracruzano. J. Ortega and C. Sanchez assisted us in the field. L.F. Carrera-Parra and M. Londoño provided helpful criticisms of the 
previous manuscript. We are also indebted to three anonymous reviewers whose comments and insights greatly improved this manuscript.

\section{REFERENCES}

Carrera-Parra, L.F. and S.I. Salazar-Vallejo. - 1998a. Eunícidos (Polychaeta) del caribe mexicano con claves para las especies del Gran Caribe: Eunice. Rev. Biol. Trop., 45(4): 1499-1521.

Carrera-Parra, L.F. and S.I. Salazar-Vallejo. - 1998b. A new genus and 12 new species of Eunicidae (Polychaeta) from the Caribbean Sea. J. Mar. Biol. Ass. U.K., 78: 145-182.

Chamberlin, R.V. - 1919. The Annelida Polychaeta of the Albatross Tropical Pacific Expedition, 1891-1905. Mem. Mus. Comp. Zool., Harvard University, 48: 1-514.

Day, J.H. - 1967. A Monograph on the Polychaeta of Southern Africa. Brit. Mus. (Nat. Hist.) Publ., 656: 1-878.

De León-González, J.A. - 1985. Eunicidae (Polychaeta) de 10 localidades en las costas mexicanas. Tésis Prof., Fac. Cienc. Biol., Univ. Autón. Nuevo León.

Dueñas, P.R. - 1981. Inventario preliminar de los poliquetos (Annelida) de aguas someras de la bahía de Cartagena y áreas adyacentes. Bol. Mus. Mar, Univ. Bogotá, 10: 82-138.

Ebbs, N.K. - 1966. The coral-inhabiting polychaetes of the northern Florida reef tract. Part. I. Aphroditidae, Polynoidae, Amphinomidae, Eunicidae and Lysaretidae. Bull. Mar. Sci., 16(3): 485-555.

Ehlers, E. - 1868. Die Borstenwürmer (Annelida Chaetopoda) nach Systematischen und Anatomishcen Untersuchungen. Erster Band. Leipzig, Verlag von Wilhelm Engelmann, pp. 269-748.

Ehlers, E. - 1887. Report on the Annelids. Reports on the Result of Dredging, Under the Direction of Pourtales \& Agassiz in the Gulf of Mexico. Mem. Mus. Comp. Zool. Harvard, 15: 1-335.

Fauchald, K. - 1970. Polychaetous annelids of the families Eunicidae, Lumbrineridae, Iphitimidae, Arabellidae, Lysaretidae and Dorvilleidae from Western Mexico. Allan Hancock Found. Monogr. Mar. Biol., 5: 1-135.

Fauchald, K. - 1992. A review of the Genus Eunice (Polychaeta: Eunicidae) based upon type material. Smithsonian Contrib. Zool., 523: 1-422.

Fauvel, P. - 1923. Polychètes Errantes. Faune de France 5: 1-488.

Fauvel, P. - 1953. The Fauna of India including Pakistan, Ceylon, Burma and Malaya. Annelida Polychaeta. Indian Press, Allahabad, pp. 1-507.

Gardiner, S.L. - 1976. Errant polychaete annelids from North Carolina. J. Elisha Mitchell Sci.Soc., 91(3): 77-220.

Gathof, J.M. - 1984. Family Eunicidae Savigny, 1818. In: J. Uebelacker and P. Johnson (eds.) Taxonomic guide to the polychaetes of the northern Gulf of Mexico. Prepared for U.S. Department of the Interior, Minerals Management Services, Barry A. Vittor and Associates, Mobile, Alabama, (4), 30: 1-151.

George, J.D and G. Hartmann-Schröder. - 1985. Polychaetes: British Amphinomida, Spintherida and Eunicida. Linnean Society of London and Estuarine and Brackish-Water Sciences Association. Bath, Great Britain.

Hartman, O. - 1944. Polychaetous annelids, 5. Eunicea. Allan Hancock Found. Pac. Exped., 10(1): 1-237

Hartman, O. - 1956. Polychaetous annelids erected by Treadwell, 1891-1948, together with a brief chronology. Bull. Am. Mus. Nat. Hist., 109(2): 243-310.

Horta-Puga, G.J. - 1982. Descripción de algunas Especies de poliquetos Bentónicos de Isla Verde, Veracruz. Tesis Prof., Univ. Nal. Autón. Méx., Esc. Nal. Est. Prof. Istacala.
Ibarzabal, D.R. - 1989. Poliquetos de Punta del Este, Isla de la Juventud, Cuba. IV. Orden Eunicida. Poeyana, 384: 1-28.

Imajima, M. - 1967. Errant polychaetous annelids from Tsukumo Bay and vicinity of Noto Peninsula, Japan. Bull.Natl.Sci.Mus., 10(4): 403-441.

Miura, T. - 1977a. Eunicid Polychaetous Annelids from Japan. I. La mer. Bull. Soc. Franco-Japonaise d'Océanogr., 15(1): 1-20.

Miura, T. - 1977b. Eunicid Polychaetous Annelids from Japan. II. La mer, Bull. Soc. Franco-Japonaise d'Océanogr., 15(2): 61-81.

Miura, T. - 1979. Eunicid Polychaetous Annelids from Japan. III. La mer, Bull. Soc. Franco-Japonaise d'Océanogr., 17(1): 33-42.

Miura, T. - 1986. Japanese Polychaetes of the Genera Eunice and Euniphysa: Taxonomy and Branchial distribution patterns. Publ. Seto Mar. Biol. Lab., 36: 269-325.

Núñez, J., M. Pascual, J.D. Delgado and M.C. Brito. - 1998. Anélidos poliquetos de Canarias: familia Eunicidae. Vieraea, 26: 47-75.

Reyes-Barragán, M.P. and S.I. Salazar-Vallejo. - 1991. Bentos asociado al pastizal de Halodule (Potamogetonaceae) en Laguna de La Mancha, Veracruz, Mexico. Rev. Biol. Trop., 38(2A): 167-173.

Rioja, E. - 1946. Estudios anelidológicos, 14. Observaciones sobre algunos poliquetos de las costas del Golfo de México. An. Inst. Biol., 17: 193-203.

Rioja, E. - 1958. Estudios anelidológicos, 22. Datos para el conocimiento de la fauna de anélidos poliquetos de las costas orientales de México. An. Inst. Biol., 29: 219-301.

Rioja, E. - 1960. Estudios anelidológicos, 24. Adiciones a la fauna de anélidos poliquetos de las costas orientales de México. An. Inst. Biol., 31: 289-316.

Salazar-Vallejo, S.I. - 1981. La Colección de Poliquetos (Annelida: Polychaeta) de la Facultad de Ciencias Biológicas de la Universidad Autónoma de Nuevo León México. Tésis Prof., Fac. Cienc. Biol., Univ. Autón. Nuevo León. Nuevo León, México.

Salazar-Vallejo, S.I. - 1985. Contribución al conocimiento de los poliquetos (Annelida: Polychaeta) de Bahía Concepción, Baja California Sur, México. Tésis Maestr., Div. Oceanol., CICESE. Ensenada, México.

Salazar-Vallejo, S.I., J.A. de León-González, G. Góngora-Garza and H. Saláices-Polanco. - 1987. Nuevos registros y extensiones de ambito de poliquetos (Annelida: Polychaeta) de México. Invest. Mar., 3: 29-38.

Salazar-Vallejo, S.I. and L.F. Carrera-Parra. - 1998. Eunícidos (Polychaeta) del Caribe mexicano con claves para las especies del Gran Caribe: Fauchaldius, Lysidice, Marphysa, Nematonereis y Palola. Rev. Biol. Trop., 45(4): 1481-1498.

Sánchez-Wall, M.I. - 1992. Comunidad de poliquetos asociados a substratos duro en el arrecife de Isla de Enmedio, Municipio de Anton Lizardo, Veracruz, México. Tésis Prof., Univ. Veracruzana, Fac. Biol., Xalapa.

Treadwell, A.L. - 1921. Leodicidae of the West Indian Region. Pap Tortugas Lab, Carnegie Inst Wash., 15: 1-131.

Treadwell, A.L. - 1939. Polychaetous annelids of Porto Rico and vicinity. NY Acad Sci Scient Survey Porto Rico Virgin Islands, 16(2): 150-319.

Webster, H.E. - 1884. Annelida from Bermuda collected by G. Brown Goode. Bull. U.S. Natl. Mus., 25: 305-327.

Westheide, W. - 1977. Interstitielle Fauna von Galapagos. XVIII. Nereidae, Eunicidae, Dorvilleidae (Polychaeta). Mikrofauna Meeresboden, 63: 1-40.

Zanol, J., P.C. Paiva and F. Silva-Attolini. - 2000. Eunice and Palola (Eunicidae: Polychaeta) from the Eastern Brazilian

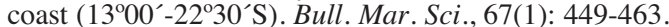

Received September 16, 2004. Accepted May 11, 2005. 